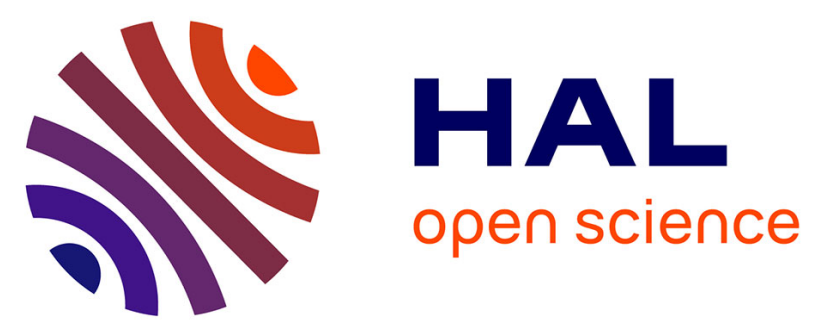

\title{
First isolation of Brevibacterium sp. pigments in the rind of an industrial red-smear-ripened soft cheese
}

Patrick Galaup, Nuthathai Sutthiwong, Marie-Noëlle Leclercq-Perlat, Alain

Valla, Yanis Caro, Mireille Fouillaud, Fabienne Guérard, Laurent Dufossé

\section{- To cite this version:}

Patrick Galaup, Nuthathai Sutthiwong, Marie-Noëlle Leclercq-Perlat, Alain Valla, Yanis Caro, et al.. First isolation of Brevibacterium sp. pigments in the rind of an industrial red-smear-ripened soft cheese. International Journal of Dairy Technology, 2015, 68 (1), pp.144-147. 10.1111/14710307.12211 . hal-01113700

\section{HAL Id: hal-01113700 \\ https://hal.univ-brest.fr/hal-01113700}

Submitted on 3 Mar 2016

HAL is a multi-disciplinary open access archive for the deposit and dissemination of scientific research documents, whether they are published or not. The documents may come from teaching and research institutions in France or abroad, or from public or private research centers.
L'archive ouverte pluridisciplinaire HAL, est destinée au dépôt et à la diffusion de documents scientifiques de niveau recherche, publiés ou non, émanant des établissements d'enseignement et de recherche français ou étrangers, des laboratoires publics ou privés. 
1 First isolation of Brevibacterium sp. pigments in the rind of an industrial

2 red-smear ripened soft cheese

3

4 PATRICK GALAUP, ${ }^{1}$ NUTHATHAI SUTTHIWONG,${ }^{2,3}$ MARIE-NOËLLE LECLERCQ-

5 PERLAT, ${ }^{4}$ ALAIN VALla, ${ }^{5}$ YANIS CARO, ${ }^{3}$ MIREILle FOUILlaUd, ${ }^{3}$ FABIENNE

6 GUÉRARD, ${ }^{1,6}$ and LAURENT DUFOSSÉ ${ }^{1,3 *}$

7

$8 \quad{ }^{1}$ Laboratoire ANTiOX, Université de Bretagne Occidentale, Pôle Universitaire Pierre-Jakez

9 Hélias, Créac'h Gwen, Quimper, France

10

$11{ }^{2}$ Agricultural Technology Department, Thailand Institute of Scientific and Technological 12 Research, Klong Luang, Pathum Thani, Thailand

13

$14{ }^{3}$ Laboratoire de Chimie des Substances Naturelles et des Sciences des Aliments, Université 15 de La Réunion, ESIROI Agroalimentaire, Parc Technologique, Sainte-Clotilde, Ile de La 16 Réunion, France

17

$18{ }^{4}$ INRA 782 Génie et Microbiologie des Procédés Alimentaires, Thiverval- Grignon, France 19

${ }^{6}$ Université Européenne de Bretagne, Institut Universitaire Européen de la Mer, Technopôle

23 Brest-Iroise, Plouzané, France

24

$25 *$ Author for correspondence. E-mail: laurent.dufosse@ univ-reunion.fr 


\section{Abstract}

3

4 The smear ripened soft cheeses are characterized by a surface orange-red-brown color which

5 has a microbial origin. For a long time this coloration was mainly imputed to Brevibacterium

6 linens. However the latest published works, based on molecular biology, have shown a minor

7 role for this bacterium. The present study shows the results obtained with an industrial cheese

8 named Vieux-Pané which is characteristic due to the presence of carotenoids from

9 Brevibacterium linens group at its surface. This demonstrates that, under certain conditions,

10 Brevibacterium linens group (Brevibacterium linens and Brevibacterium aurantiacum sp.

11 nov.) is able to produce pigments and to colour effectively cheeses.

12

13 Keywords Brevibacterium linens, Carotenoid, Isorenieratene, Cheese rind, Color.

14

15

16

17 
3 A previous study from our laboratory presented an extraction method for the analysis of

4 pigments in the cheese rinds (Galaup et al. 2005). This method was then applied to high 5 quality red-smear soft cheeses such as those under the "Protected Designation of Origin 6 (PDO)" legislation and the first pigment fingerprints of such cheeses were obtained (Galaup 7 et al. 2005). It has also shown that the origin of pigments seems essentially related to the presence of yellow bacteria such as Arthrobacter or Microbacterium species (Galaup et al. 2007), the pigments of Brevibacterium linens group being only present at trace amounts on Maroilles (Guyomarc'h et al. 2000a) [Supplementary materials 1\&2]. All these studies seem to confirm the minor role of Brevibacterium linens group in cheese colouring.

We have recently applied this method to different industrial cheeses, and this paper shows the pigment fingerprint of the rind of Vieux-Pané produced in France, which is characterized by the predominant presence of pigments from Brevibacterim linens group.

\section{MATERIALS AND METHODS}

Bacterial strains, culture media, cheeses, extraction of pigments and HPLC conditions were 18 described in previous publications (Guyomarc'h et al. 2000b; Galaup et al. 2005). [Supplementary material 3].

\section{RESULTS AND DISCUSSION}

\section{HPLC profiles of the Brevibacterium linens extracts}

24 For all strains investigated (Brevibacterium linens and Brevibacterium aurantiacum sp. nov.), 25 the color reaction of biomass or methanol extracts in the presence of alkali is positive. It is 
1 due to the ionization of phenols into phenolates in both mono- and di-hydroxylated

2 isorenieratene derivatives (Britton et al. 1995). This reaction is characteristic of the pigments

3 of Brevibacterium linens group. Moreover, all strains (over one hundred strains tested up to

4 now in all of our experiments -including the 30 strains of the present work) have shown the

5 same typical chromatogram, even if some of these strains (e.g. ATCC 9175) are reclassified

6 as Brevibacterium aurantiacum (Gavrish et al. 2004). Even if it is possible to differentiate

7 these two species by molecular biology methods, they show the same pigment fingerprint and

8 develop a carmine-red color in contact with strong alkali.

9 The chromatographic profile of Brevibacterium linens or Brevibacterium aurantiacum

10 (Figure 1A) consisted of a series of three groups of peaks (Guyomarc'h et al. 2000b). The

11 first group (I) was eluted between 15 and 22 minutes. A main peak elutes between (15-17

$12 \mathrm{~min}$ ) followed at $1.5 \mathrm{~min}$ by a smaller one. Between 17 and 18 minutes, 2 other peaks were

eluted. The second group (II) consisted of a series of small peaks eluted between 30 and 45

minutes. The last group of peaks (III), slightly detected was eluted between 70 and 80 min.

The three groups of peaks were identified as respectively related to 3,3'-dihydroxyisorenieratene (group I), 3-hydroxy-isorenieratene (group II) and isorenieratene (group III). On synthetic medium, Brevibacterium linens produced mainly the 3,3'-dihydroxyisorenieratene. The groups representing the 3-monohydroxy and isorenieratene were present only as traces.

By the study of UV/visible spectrum, more information could be obtained such as cis/trans isomerisation (Schieber and Carle 2005) or hydroxylation. The identification of the cis compounds was possible due to their characteristic 'cis-peak' (320-380 nm, see 
1 Supplementary material 4). Moreover, when a compound is hydroxylated, it becomes more

2 polar and presents a more rounded UV/visible spectrum.

3 The compounds which are eluted in each group seem to be isomers of the same molecule.

4 Indeed, like in the case of lycopene (Chasse et al. 2001; Ishida et al. 2001), a quite high

5 number of cis/trans isomers of isorenieratene, mono-hydroxy-isorenieratene and di-hydroxy-

6 isorenieratene could be obtained, based on the position of the isomerisation (Figure 2, cis

7 isomers of 3-3'-dihydroxy-isorenieratene).

8

9

10

11 HPLC profiles of the cheese extracts

12 The profile presents the three distinct groups of pigments very characteristic of 13 (insert Figure 2) 
1 group of 3,3'-dihydroxy-isorenieratene (RT from 12 to $18 \mathrm{~min}$ ) present in synthetic medium

2 and cheese matrix was clear. Even if the concentrations in pigments of groups II and III were 3 very different among the 2 profiles, the molecules were identical. The pigments extracted

4 from the cheese rind represented all isomers of isorenieratene and hydroxyl derivatives

5 described in Brevibacterium linens by Kohl et al. (Kohl et al. 1983).

6 Pigments of the groups II and group III are not generally detected at this high level of 7 concentration in the extracts of pigments resulting from Brevibacterium linens cultivated in synthetic media. It was thus the first time that the three groups of pigment with as much of

9 intensity and resolution are detected.

The presence of these molecules on the rind of cheeses raises some questions about their production. Was the production of these molecules induced by factors (e.g biotic, physicochemical...) which are not present or effective on synthetic culture medium? Was an interaction with other microorganisms (e.g yeasts, bacteria) necessary for the production of substantial amounts of mono-hydroxy-isorenieratene and isorenieratene? In the literature the study of the production of pigments from this bacterium was primarily and mainly conducted with synthetic culture media. In the future, it would be judicious to use complex and/or dairy media reflecting more the composition of a cheese, such as curd models or "cheese models" used by Leclercq-Perlat et al. (Leclercq-Perlat et al. 2004).

Latest studies concerning the microflora of red-smear ripened soft cheeses showed a weak presence of Brevibacterium linens group. Bockelmann (Bockelmann 2002) reported that 21 Arthrobacter nicotianae, pigmented in yellow, accounts for 5 to $10 \%$ of the bacteria isolated 22 from Tilsit whereas Brevibacterium linens accounts for 0.1 to $10 \%$ (Bockelmann et al. 2005). In Comté, less than $1 \%$ of the total flora consists of Brevibacterium linens (Bockelmann et al. 2005). The 16S DNA sequences coding for Brevibacterium linens are almost not detected at the end of the ripening of red-smear ripened soft cheeses, the bacteria present being especially 
1 species of Arthrobacter (Feurer et al. 2004). In French PDO red smear cheeses, the

2 Brevibacterium linens pigment fingerprint was only slightly detected on the Maroilles cheese

3 (Galaup et al. 2007). With all these various works and results, the tendency was to minimize

4 the role of Brevibacterium linens to the profit of other microorganisms (Goerges et al. 2008;

$5 \quad$ Mounier et al. 2006).

6 Since 1997, Bockelmann and his team have studied which bacterium could lead to the 7 complete formation of cheese models close to Tilsit from a point of view of odor and color.

8 When the sole presence of Brevibacterium linens produced imperfect cheeses, the

9 combination of Brevibacterium linens with Arthrobacter sp. led to acceptable cheeses. More complex combinations between Debaryomyces hanseni, Arthrobacter sp. (yellow strain) and Staphylococcus sp. (pigmented and not pigmented strain) could give color and odor similar to those of Tilsit (Bockelmann 2002; Bockelmann et al. 2005). The whole of this work led to an effective cocktail of microorganisms for the ripening of Tilsit containing 5 species: Debaryomyces hansenii, Brevibacterium linens, Staphylococcus equorum (S. sciuri),

Corynebacterium ammoniagenes, and Arthrobacter nicotianae (Bockelmann 2002;

Bockelmann et al. 2005).

Our study, in the case of this French industrial cheese Vieux-Pané, demonstrated that a strain from Brevibacterium linens group was able to produce pigments and impart color to a cheese with efficacy. The biodiversity of the bacterial flora on the surface of cheese is important (Brennan et al. 2002; Bokulich and Mills 2013). In this case of industrial cheeses (Gori et al. 21 2013; Feligini et al. 2012), the composition of the various microorganisms seeded during the 22 process is not known and is confidential. It may occur that Brevibacterium linens did not have to undergo competition with other microorganisms and that its development at the cheese surface could happen in an optimal way. 
2 The weak occurrence of Brevibacterium linens and Brevibacterium aurantiacum sp. nov. at 3 the surface of red-smear ripened soft cheeses has been shown in previous studies and the role

4 of these bacteria on the development of cheese color has been minimized. In fact, cheese rind 5 coloration is a complex process and our results showed that this group of bacteria, under 6 certain conditions, was quite able to give color to cheese surface. So, the role of $7 \quad$ Brevibacterium linens group is not negligible.

8 Future research would explain why this group of bacteria (always present at the earliest stage 9 of ripening) produced pigments on certain cheeses and not on others.

\section{ACKNOWLEDGEMENTS}

12

This work was supported by ACTIA (Association de coordination technique pour l'industrie 14 agro-alimentaire) research programmes, the French Minister of National Education, Research and Technology, Degussa France and four Protected Designation of Origin cheese-makers. Patrick Galaup is grateful to Dr. Régis Moreau (Linus Pauling Institute, Corvallis, USA) for helpful discussion. Laurent Dufossé thanks the so-called 'Carotenoid triumvirate', Synnøve Liaaen-Jensen, Hanspeter Pfander and George Britton for nice discussions about carotenoids, these fascinating chemical compounds.

Laurent Dufossé, Yanis Caro and Mireille Fouillaud would like to thank to the Conseil Régional de La Réunion, Reunion Island, France, for financial support of research activities dedicated to microbial pigments. 
REFERENCES

2 Bockelmann W (2002) Development of defined surface starter cultures for the ripening of smear cheeses. International Dairy Journal 12 123-131.

Bockelmann W, Willems K P, Neve H and Heller K J (2005) Cultures for the ripening of smear cheeses. International Dairy Journal 15 719-732.

Bokulich N A and Mills D A (2013) Facility-specific "house" microbiome drives microbial landscapes of artisan cheesemaking plants. Applied and Environmental Microbiology 79 $5214-5223$.

Brennan N M, Ward A C, Beresford T P, Fox P F, Goodfellow M and Cogan T M (2002) Biodiversity of the bacterial flora on the surface of a smear cheese. Applied and Environmental Microbiology 68 820-830.

Britton G, Liaaen-Jensen S, Pfander H (1995) Carotenoids today and challenges for the future. pp 13-26. In Carotenoids, volume 1A : Isolation and analysis, Britton G, LiaaenJensen S, Pfander H. (Eds.) Birkhäuser Publ.

Chasse G A, Mak M L, Deretey E, Farkas I, Torday L L, Papp J G, Sarma D S R, Agarwal A, Chakravarthi S, Agarwal S and Rao A V (2001) An ab initio computational study on selected lycopene isomers. Journal of Molecular Structure 571 27-37.

Feligini M, Panelli S, Buffoni J N, Bonacina C, Andrighetto C and Lombardi A (2012) Identification of microbiota present on the surface of Taleggio cheese using PCR-DGGE and RAPD-PCR. Journal of Food Science 77 M609-M615.

Feurer C, Vallaeys T, Corrieu G and Irlinger F (2004) Does smearing inoculum reflect the bacterial composition of the smear at the end of the ripening of a French soft, red-smear cheese? Journal of Dairy Science 87 3189-3197. 
1 Galaup P, Flamin C, Carlet E and Dufossé L (2005) HPLC analysis of the pigments produced

2 by the microflora isolated from the 'Protected Designation of Origin' French red-smear 3 soft cheeses Munster, Epoisses, Reblochon and Livarot. Food Research International 38 $855-860$.

Galaup P, Gautier A, Piriou J, de Villeblanche A, Valla A and Dufossé L (2007) The first pigment fingerprints obtained from the rind of French red-smear ripened soft cheeses. Innovative Food Science and Emerging Technologies 8 373-378.

Gavrish E Y, Krauzova V I, Potekhina N V, Karasev S G, Plotnikova E G, Altyntseva O V, Korosteleva L A and Evtushenko L I (2004) Three new species of brevibacteria, Brevibacterium antiquum sp. nov., Brevibacterium aurantiacum sp. nov., and Brevibacterium permense sp. nov. Microbiology 73 176-183.

Goerges S, Mounier J, Rea M C, Gelsomino R, Heise V, Beduhn R, Cogan T M, Vancanneyt M and Scherer S (2008) Commercial ripening starter microorganisms inoculated into cheese milk do not successfully establish themselves in the resident microbial ripening consortia of a south German red smear cheese. Applied and Environmental Microbiology 74 2210-2217.

Guyomarc'h F, Binet A and Dufossé L (2000a) Characterization of Brevibacterium linens pigmentation using spectrocolorimetry. International Journal of Food Microbiology 57 201-210.

Guyomarc'h F, Binet A and Dufossé L (2000b) Production of carotenoids by Brevibacterium linens : variation among strains, kinetic aspects and HPLC profiles. Journal of Industrial Microbiology and Biotechnology 24 64-70. 
1 Ishida B K, Ma J and Chan B (2001) A simple, rapid method for HPLC analysis of lycopene 2 isomers. Phytochemical Analysis 12 194-198.

3 Kohl W, Achenbach H and Reichenbach H (1983) The pigments of Brevibacterium linens:

$4 \quad$ aromatic carotenoids. Phytochemistry 22 207-210.

5 Leclercq-Perlat M N, Corrieu G and Spinnler H E (2004) The color of Brevibacterium linens 6 depends on the yeast used for cheese deacidification. Journal of Dairy Science 87 1536$7 \quad 1544$.

8 Mounier J, Fitzgerald G F and Cogan T M (2006) Survival of surface ripening cultures during storage and monitoring their development on cheese. Letters in Applied Microbiology $\mathbf{4 2}$ $425-431$.

Schieber A and Carle R (2005) Occurrence of carotenoid cis-isomers in food: Technological, analytical, and nutritional implications. Trends in Food Science and Technology 16 416422. A new biomimetic-like aromatization of the cyclic end groups of terpenoids with stereospecific migration of one of the methyl groups: A convenient route to isorenieratene ( $\phi, \phi$-carotene). European Journal of Organic Chemistry 4 711-715. 


\section{List of captions}

2

3 Figure 1 Chromatographic profile of pigments from Brevibacterium aurantiacum ATCC

49175 methanolic extract (A) and chromatographic profile of pigments extracted from the rind 5 of Vieux-Pané red-smear soft cheese (B).

6

7

8 Figure 2 Isomers of 3,3'-dihydroxy-isorenieratene, concerning only one isomerisation of the

9 ethylenic linkage (the most probable), i.e. the all trans isomer and the five cis isomers that

10 could occur. Cis isomers are named from A to E, starting from the middle of the molecule. *

11 indicates a steric hindrance. Similar isomers could be described for non hydroxylated 12 isorenieratene and 3-hydroxy-isorenieratene.

13

14 


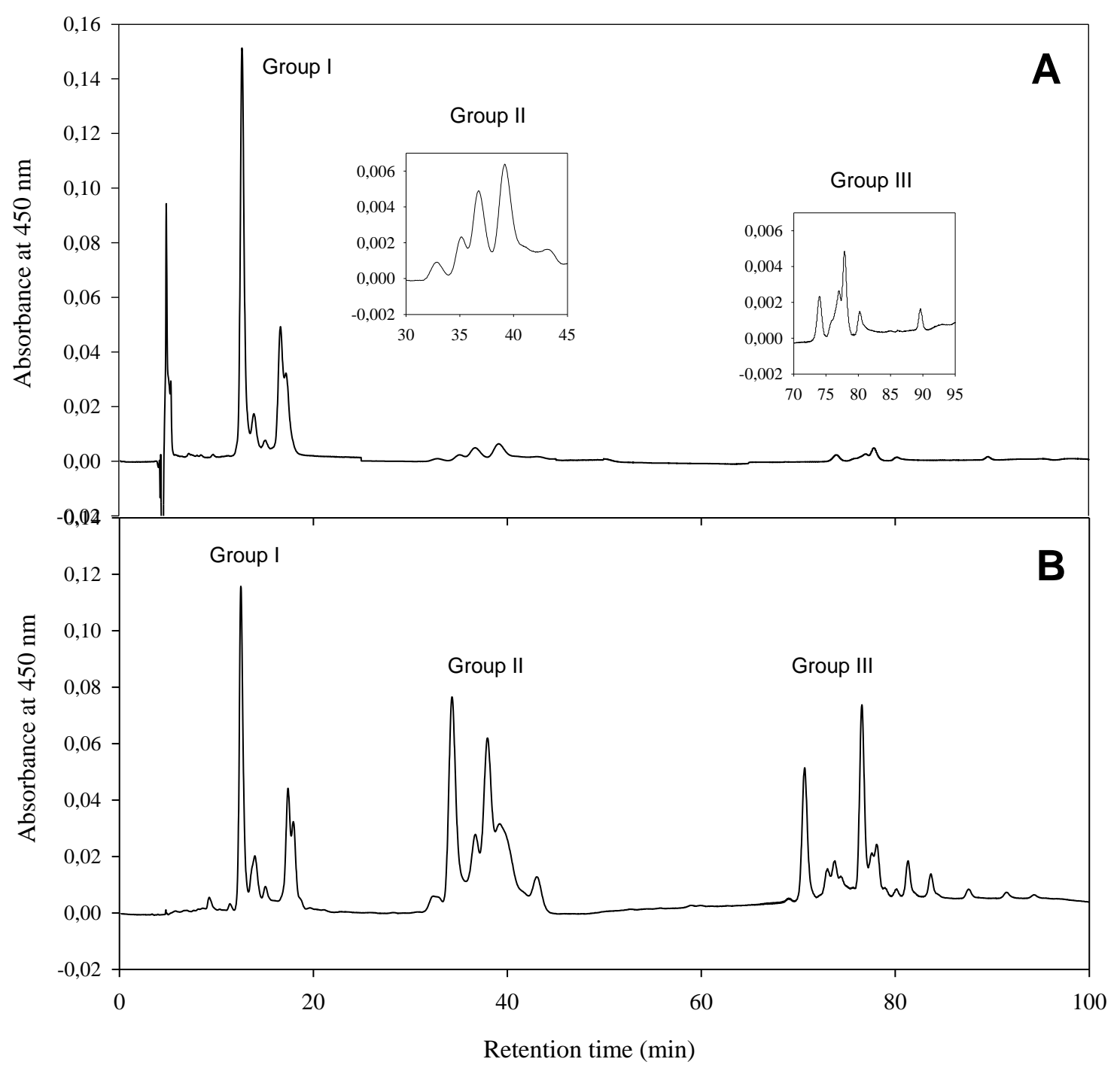

3

4

Figure 1

5 

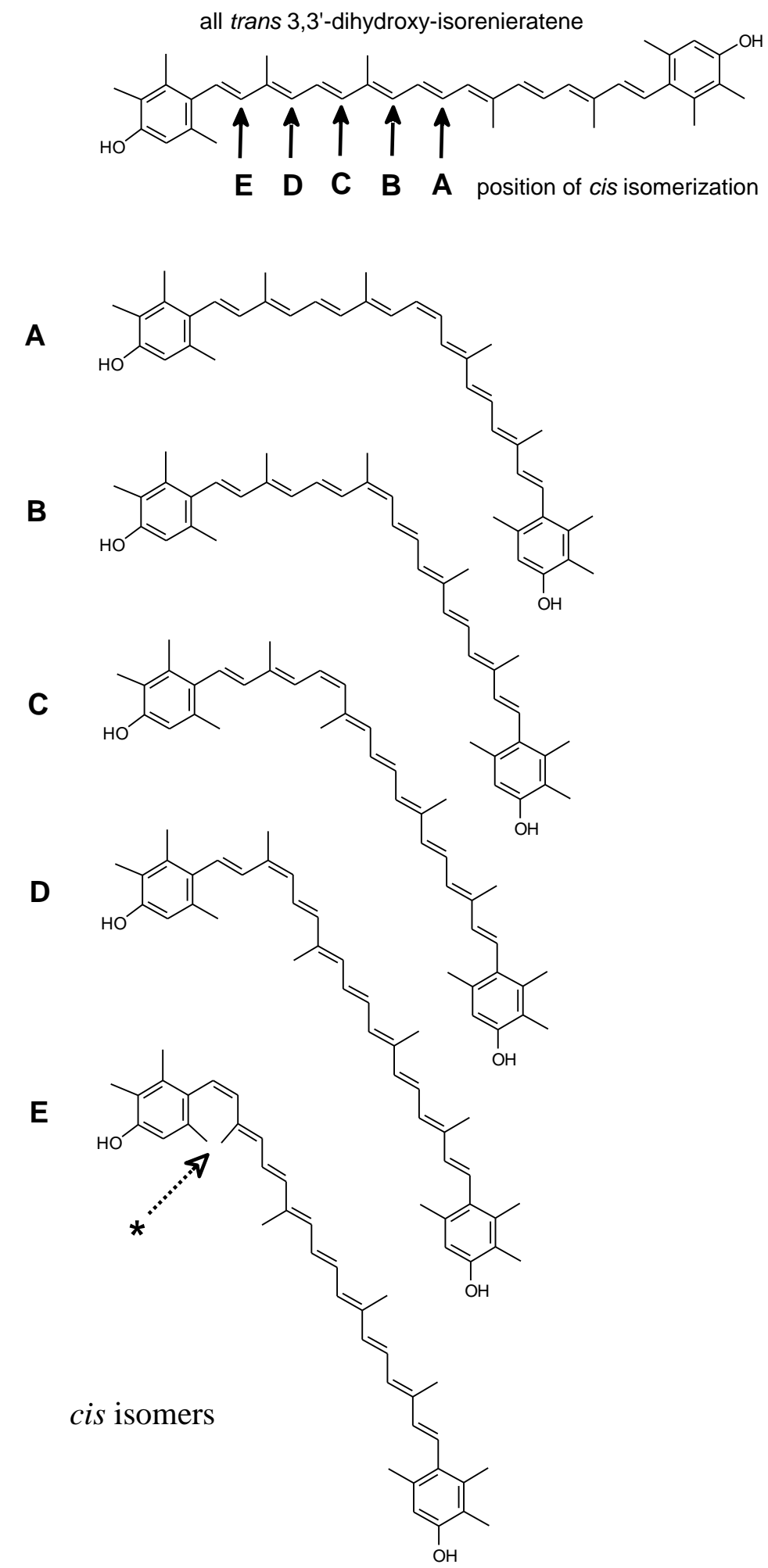

Figure 2

4 
1 Supplementary material 1

2

3

4

5

6

7

8

9

10

11

12

13

14

15

16

17

18

19

20

21

22

Smear-cheeses with rinds colored by a bacterial microflora. 1a. Livarot, 1b. Rollot in the ripening cellar, 1c. Hand-made washing of Munster, 1d. Maroilles.
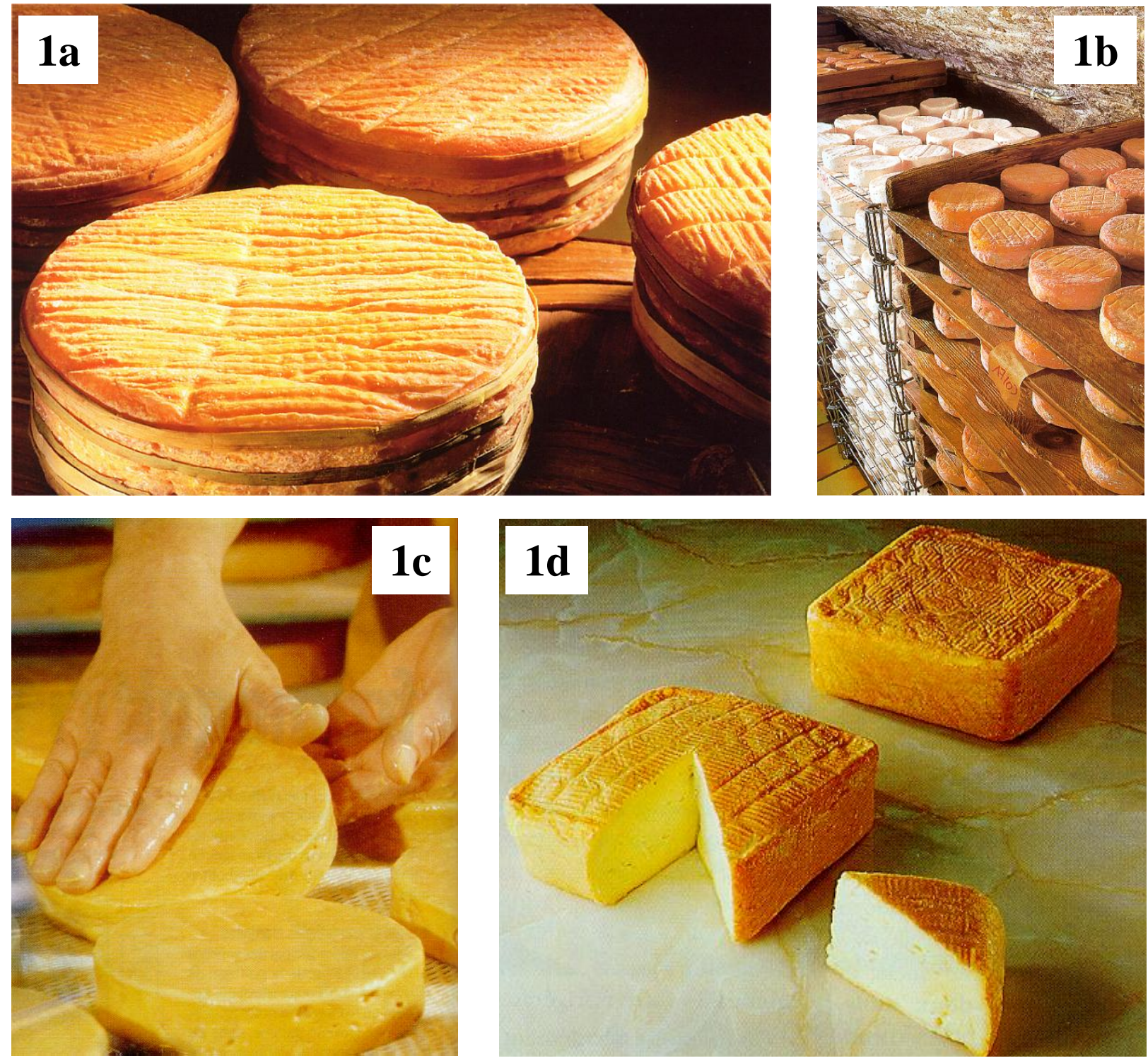

The appearance of foodstuffs, of cheeses is one of the only permitted ways to appreciate onsell food products (Aydemir and Dervisoglu 2010; Fresno and Alvarez 2012). For so-called red-smear cheeses like Maroilles, Munster, Livarot, Epoisses, Limburger, Herve, Gubbeen, Taleggio or Tilsit, a good aspect is mostly characterized by the occurrence of an homogeneous orange-red-brown, sticky surface (above pictures). 
1 Except for artificially colored cheeses, the color is due to pigments produced by the cheese

2 microflora during ripening. For a long time the coloration of red-smear ripened soft cheeses

3 was only imputed to Brevibacterium linens. The pigments produced by Brevibacterium linens

4 were first identified as aromatic carotenoids (Supplementary material 2) (Kohl et al. 1983),

5 and later characterized within the L*a*b* color system (Guyomarc'h et al. 2000; Dufossé et

6 al. 2001). In fact, cheese rind coloration is a complex process involving physical and

7 chemical parameters, such as temperature, dissolved oxygen, $\mathrm{pH}$, culture medium, lightness, and/or biotic interactions, all important for bacterial development and pigment production (Irlinger and Mounier 2009). Studies have shown that the ripening of red-smear ripened soft cheeses progresses through the succession of microbial communities on the cheese surface (Mounier et al. 2009. This surface microflora, named the smear, is mainly composed of yeasts and surface bacteria. First, from the earliest hours of cheese-making and during the first six days of ripening, the yeasts make up the main species and Debaryomyces hansenii grow by consuming lactose and lactate at the same time but with different specific consumption rates (Leclercq-Perlat et al. 2000). Moreover, they produce a lot of compounds such as aroma compounds and growth factors essential for bacterial development as supported by Corsetti et al. (Corsetti et al. 2001). Through this ripening period (day 0 - day 6), yeasts deacidify the surface and when $\mathrm{pH}$ increases to a value higher than 6 , surface bacteria begin to grow and eventually cover the entire cheese surface, forming the main population at the end of ripening. However, some bacterial strains such as Arthrobacter sp. can grow at a lower $\mathrm{pH}$ (5.4). The surface bacterial composition depends on the smear cheeses under study. These bacteria belong to Arthrobacter sp., Brevibacterium sp., Corynebacterium sp., Microbacterium sp., Micrococcus sp., and Rhodococcus sp. (Bockelmann 2002). Even if Brevibacterium linens is considered as the main pigmentation and flavouring bacterium for this type of cheeses, it does not form the main bacterial species of the smear throughout the ripening. Bockelmann et al. 
1 (Bockelmann et al. 2005) have also shown that the pigmentation of the smear is due to some

2 interactions between surface bacteria and the matrix. Interactions between the yeast

3 Debaryomyces hansenii and coryneform bacteria were shown to influence cheese surface

4 pigmentation (Masoud and Jakobsen 2003; Leclercq-Perlat et al. 2004). Among these

5 bacteria, the well-known bacterium species on the smear are belonging to the Brevibacterium

6 linens group (Gavrish et al. 2004), and the species essentially isolated from the smear cheeses

7 are Brevibacterium linens and Brevibacterium aurantiacum.

8 Considering the small content of Brevibacterium linens group in the smear, Bockelmann

9 (Bockelmann 2002) expressed reserves that Brevibacterium linens alone would contribute to

10 the rind coloration. Using cheese model system, they first reported about the importance of

11 Brevibacterium linens interactions with other bacteria, such as Arthrobacter sp. in the

12 development of cheese coloration (Bockelmann et al. 2005). More recently, it was shown by

13 molecular biology methods that in some types of red-smear ripened soft cheeses,

14 Brevibacterium linens was not even found at the end of the ripening process (Feurer et al.

15 2004).

16

Aydemir O and Dervisoglu M (2010) The effect of heat treatment and starter culture on colour intensity and sensory properties of Kulek cheese. International Journal of Dairy Technology 63 569-574.

20 Bockelmann W (2002) Development of defined surface starter cultures for the ripening of smear cheeses. International Dairy Journal 12 123-131.

Bockelmann W, Willems K P, Neve H and Heller K J (2005) Cultures for the ripening of smear cheeses. International Dairy Journal 15 719-732.

Corsetti A, Rossi J and Gobbetti M (2001) Interactions between yeasts and bacteria in the smear surface-ripened cheeses. International Journal of Food Microbiology 69 1-10. 
1 Dufossé L, Mabon P and Binet A (2001) Assessment of the coloring strength of

2 Brevibacterium linens strains: spectrocolorimetry versus total carotenoid extraction / 3 quantification. Journal of Dairy Science 84 354-360.

4 Feurer C, Vallaeys T, Corrieu G and Irlinger F (2004) Does smearing inoculum reflect the bacterial composition of the smear at the end of the ripening of a French soft, red-smear cheese? Journal of Dairy Science 87 3189-3197.

7 Fresno M and Alvarez S (2012) Chemical, textural and sensorial changes during the ripening of Majorero goat cheese. International Journal of Dairy Technology 65 393-400.

Gavrish E Y, Krauzova V I, Potekhina N V, Karasev S G, Plotnikova E G, Altyntseva O V, Korosteleva L A and Evtushenko L I (2004) Three new species of brevibacteria, Brevibacterium antiquum sp. nov., Brevibacterium aurantiacum sp. nov., and Brevibacterium permense sp. nov. Microbiology 73 176-183.

Guyomarc'h F, Binet A and Dufossé L (2000) Characterization of Brevibacterium linens pigmentation using spectrocolorimetry. International Journal of Food Microbiology 57 201-210.

Irlinger F and Mounier J (2009) Microbial interactions in cheese: implications for cheese quality and safety. Current Opinion in Biotechnology 20 142-148.

Kohl W, Achenbach H and Reichenbach H (1983) The pigments of Brevibacterium linens: aromatic carotenoids. Phytochemistry 22 207-210.

Leclercq-Perlat M N, Corrieu G and Spinnler H E (2004) The color of Brevibacterium linens depends on the yeast used for cheese deacidification. Journal of Dairy Science 871536 1544.

Leclercq-Perlat M N, Oumer A, Bergere J L, Spinnler H E and Corrieu G (2000) Behavior of Brevibacterium linens and Debaryomyces hansenii as ripening flora in controlled 
1 production of smear soft cheese from reconstituted milk: Growth and substrate 2 consumption. Journal of Dairy Science 83 1665-1673.

3 Masoud W and Jakobsen M (2003) Surface ripened cheese: the effect of Debaryomyces

4 hansenii, $\mathrm{NaCl}$ and $\mathrm{pH}$ on the intensity of pigmentation produced by Brevibacterium linens

$5 \quad$ and Corynebacterium flavescens. International Dairy Journal 13 231-237.

6 Mounier J, Monnet C, Jacques N, Antoinette A and Irlinger F (2009) Assessment of the

7 microbial diversity at the surface of Livarot cheese using culture-dependent and $8 \quad$ independent approaches. International Journal of Food Microbiology 133 31-37.

9

10

11

12

13

14

15

16 


\section{Supplementary material 2}

3

4

Aromatic carotenoids described in Brevibacterium linens according to Kohl et al. (1983).

6

7

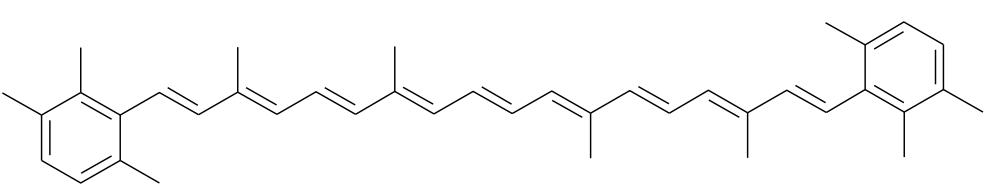

isorenieratene

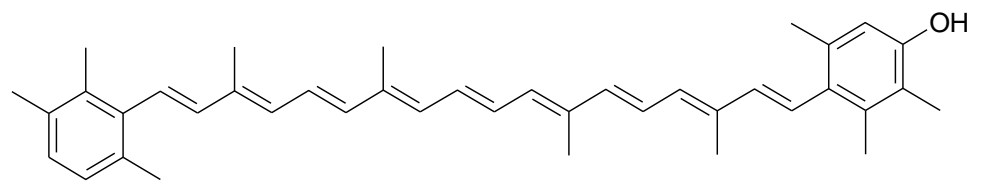

3-hydroxy-isorenieratene

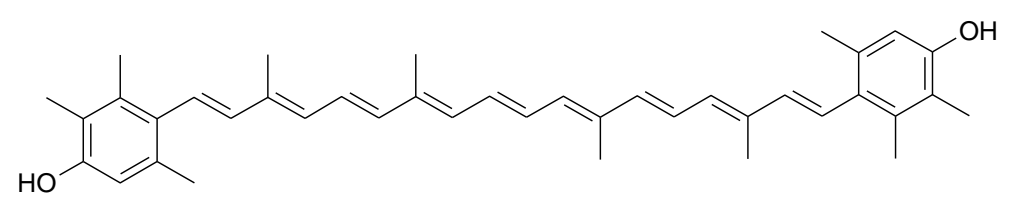

3,3'-di-hydroxy-isorenieratene

Kohl W, Achenbach H and Reichenbach H (1983) The pigments of Brevibacterium linens: aromatic carotenoids. Phytochemistry 22 207-210. 


\section{Supplementary material 3}

3

4 Material and Methods

Brevibacterium linens analysis

Bacterial strains and culture medium

7 A collection of 30 strains of Brevibacterium linens group was used, consisting of references strains, industrial strains and strains isolated from the French red-smeared cheeses' rinds.

Strains ATCC 9172 (B. linens reference strain), ATCC 9175 (B. aurantiacum reference strain) and ATCC 19391 were obtained from the American Type Culture Collection

11 (Manassas, VA, USA) and NRRL B-4210 was obtained from the Northern Regional Research

12 Laboratory (Peoria, IL, USA).

13 Cultures were grown in $250 \mathrm{~mL}$ Erlenmeyer flasks containing $50 \mathrm{~mL}$ of a medium composed of $20 \mathrm{~g} / \mathrm{L} \mathrm{D}$-glucose (Carlo Erba), $5 \mathrm{~g} / \mathrm{L}$ casamino acids (Difco), $1 \mathrm{~g} / \mathrm{L}$ yeast extract (Biokar), $5 \mathrm{~g} / \mathrm{L} \mathrm{NaCl}$ and $1 \mathrm{~g} / \mathrm{L} \mathrm{KH}_{2} \mathrm{PO}_{4}$. The $\mathrm{pH}$ was adjusted to 6.9 and the medium was heatsterilized at $121^{\circ} \mathrm{C}, 15 \mathrm{~min}$. Flasks were inoculated with $1 \%$ of 72 hour-old preculture (v/v) $\left(25^{\circ} \mathrm{C} ; 150 \mathrm{rpm}\right)$, and incubated at $25^{\circ} \mathrm{C}$ for 4 days with stirring $(150 \mathrm{rpm})$ to oxygenate the medium.

\section{Extraction of pigments from bacteria}

Extracts were obtained from $20 \mathrm{~mL}$ of culture. Cells were first centrifuged at $6,000 \mathrm{~g}$ for 15 min. The supernatant was discarded and the cell aggregate was rinsed with $5 \mathrm{~mL}$ deionized water, vortexed and centrifuged at $6,000 \mathrm{~g}$ for $15 \mathrm{~min}$. The cell aggregate was then mixed with $8 \mathrm{~mL}$ methanol, blended to prevent clotting, and extracted with constant agitation (50 rpm), protected from direct light with aluminium foil, until cells were bleached (within 2 hours). The sample was then centrifuged $(6,000 \mathrm{~g}, 15 \mathrm{~min})$, the cell aggregate was discarded 
1 and the supernatant further centrifuged (10,000 $g$ for $15 \mathrm{~min})$. The resulting supernatant, i.e.

2 methanol extract, was then injected in the HPLC system.

Biomass reaction with strong alkali

5 The pigment of Brevibacterium linens, located in the cell membrane, reacted with strong

6 alkali, leading to a deep pink-red color. This is explained by the ionization of phenolic rings at 7 high $\mathrm{pH}$, giving a subsequent bathochromic shift and seems to be specific to the diol 8 molecule. Extracted biomass was laid out on an inert white surface (i.e. Whatman paper), and 9 a few drops of $5 \mathrm{M} \mathrm{NaOH}$ were added. The test was positive if a characteristic carmine-red 10 color appeared.

HPLC analysis of the pigments extracted from the microbial biomass

Methanol extracts were evaporated to dry under reduced pressure at $75^{\circ} \mathrm{C}$ in a Büchi rotavapor, within 5 minutes. Dry pigment extracts were dissolved in $1 \mathrm{~mL}$ methanol, filtered through Millex-GV 0.2- $\mu$ m hydrophilic membrane (Millipore), and injected (20 $\mu \mathrm{L}$ ) onto a

16 LichroCART 250-4 RP-18 (250 x $4 \mathrm{~mm}, 5-\mu \mathrm{m}$ particle size) column (Merck). The HPLC apparatus consisted of Waters 600 constant flow pump and controller, and Waters 996 photodiode array detector (detection between 300 and $600 \mathrm{~nm}$ ). Separation was achieved using reverse phase HPLC at a flow rate of $0.5 \mathrm{~mL} / \mathrm{min}$. Solvents and conditions used for separation were as follows: 0 to $45 \mathrm{~min}, 100 \%$ methanol; 45 to $80 \mathrm{~min}, 100 \%$ methanol to

$2180 \%$ methanol/20\% chloroform; 80 to $130 \mathrm{~min}, 80 \%$ methanol/20\% chloroform.

\section{Cheese analyses}

24 Cheeses

25 Vieux-Pané cheeses were purchased in retail outlets (at least 3 cheeses from the same batch). 26 At reception, cheeses were placed into polyethylene bags and stored at $-20^{\circ} \mathrm{C}$. 
2 Alkaline hydrolysis and extraction of pigments from the cheese rind

3 The carotenoid extraction of milk and its derivatives is very difficult because this matrix has a

4 high lipidic content (Oliver and Palou 2000). Alkaline hydrolysis of the dairy material and

5 pigment extraction were adapted from Ollilainen et al. (Ollilainen et al. 1989). Prior to

6 pigment extraction, cheeses were thawed in the dark at $4^{\circ} \mathrm{C}$. The smear was collected by

7 scraping the surface of the cheese, weighed, and hydrolysed in $40 \mathrm{~mL}$ of concentrated $\mathrm{KOH}$

8 solution (100 g KOH dissolved in $100 \mathrm{~mL}$ water), $40 \mathrm{~mL}$ water supplemented with $1 \mathrm{~g}$

9 ascorbic acid, and $100 \mathrm{~mL}$ ethanol for 16 hours in the dark at $4^{\circ} \mathrm{C}$. No adverse effect of

10 alkaline hydrolysis on pigment contents and quality was observed. The hydrolysate was

11 transferred into a $500 \mathrm{~mL}$ separatory funnel. The flask used for hydrolysis was rinsed with

$12100 \mathrm{~mL}$ of $10 \% \mathrm{NaCl}$. One hundred $\mathrm{mL}$ of hexane:diethyl ether (70:30) were added and the

13 funnel was hand shaken for $5 \mathrm{~min}$. The aqueous phase was re-extracted two times with 100

$14 \mathrm{~mL}$ hexane-diethyl ether. The emulsion was carefully broken with few drops of ethanol. The pooled organic phases were evaporated to dry with a Büchi rotavapor on a water bath, set at $40^{\circ} \mathrm{C}$. The residue was reconstituted in $1.5 \mathrm{~mL}$ methanol:chloroform (80:20) for pigment quantification and HPLC analysis.

\section{HPLC analysis of pigments extracted from the cheese rind}

The pigment extracts resulting from cheeses are analyzed under the same conditions as the pigment extracts resulting from the bacterial cultures.

Oliver J and Palou A (2000) Chromatographic determination of carotenoids in foods. Journal of Chromatography A $\mathbf{8 8 1}$ 543-555.

Ollilainen V, Heinonen M, Linkola E, Varo P, and Koivistoinen P (1989) Carotenoids and 


\section{Supplementary material 4}

3

4
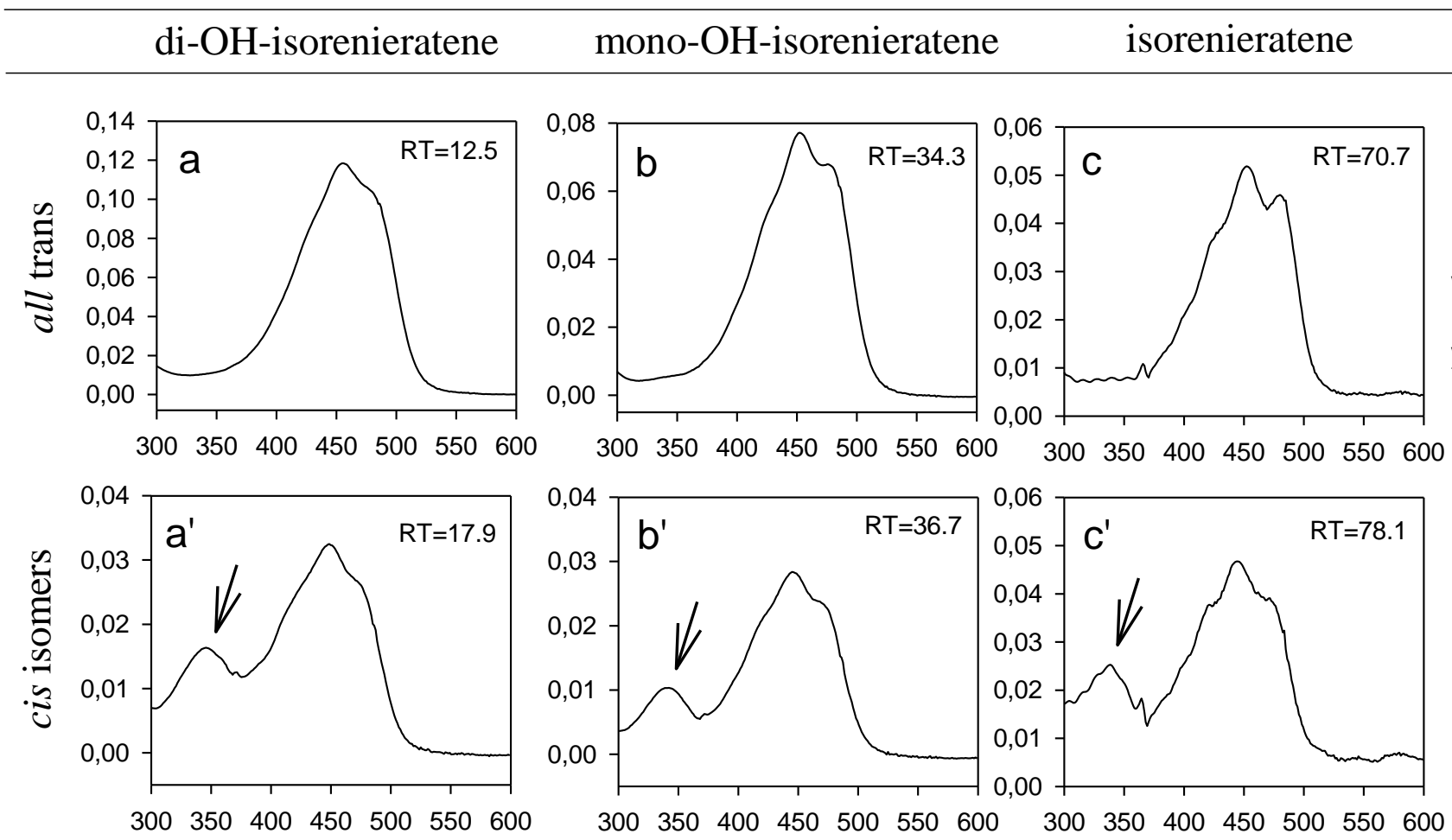

Wavelength (nm) 